\title{
GAYA PENGAJARAN DALAM KALANGAN GURU TABIKA KEMAS DI KELANTAN
}

Teaching Styles Among Teachers Kemas in Kelantan

\author{
Mazeni Ismail ${ }^{1}$, Hasmadi Hassan ${ }^{2}$ \\ Fakulti Sains Sosial \& Kemanusiaan Kolej Poly-Tech MARA Kota Bharu 15050 Kelantan ${ }^{1}$, \\ Fakulti Sains Teknologi Universiti Malaysia 26600 Pekan Pahang ${ }^{2}$ \\ mazeni@gapps.kptm.edu.my ${ }^{1}$, hasmabinhassan@gmail.com²
}

\begin{abstract}
ABSTRAK
Kajian ini bertujuan untuk mengenal pasti gaya pengajaran yang diamalkan oleh guru-guru di Tabika Kemas di negeri Kelantan. Lima puluh buah Tabika Kemas yang telah terlibat dalam kajian ini yang dipilih secara persampelan strata dan guru-guru memenuhi kriteria yang ditetapkan. Instrumen kajian yang digunakan adalah soal selidik yang telah diubahsuai daripada Grasha (1996) iaitu Inventori Gaya Mengajar Guru Teaching Styles Inventory. Seramai 50 orang guru-guru Kemas telah terlibat sebagai sampel kajian. Semua data yang diperolehi dianalisis dengan menggunakan perisian komputer Statistical Package for Science Social (SPSS) Version 22.0. Hasil kajian yang dipraktikkan oleh guru-guru dalam kajian ini adalah gaya pengajaran pakar ( $\min 3.5$ ), autoriti formal (min 3.37), model interpersonal ( $\min 3.5$ ), fasilitator $(\min 3.88)$ dan juga gaya pengajaran delegator ( $\min 4.06$ ). Kebanyakan guru menggunakan gaya pengajaran delegator iaitu nilai min 4.06 manakala gaya pengajaran yang kurang digunakan ialah gaya pengajaran fasilitator nilai min 3.38. Kesimpulannya guru-guru di Tabika Kemas menggunakan gaya pengajaran secara delegator, ini kerana latar belakang pendidikan mereka bukan secara formal dalam pendidikan awal kanak-kanak.
\end{abstract}

Kata Kunci: pengajaran, gaya pengajaran guru, gaya pengajaran Grasha

\section{ABSTRACT}

This study aims to identify the teaching styles practiced by teachers in the Tabika Kemas in Kelantan state. Fifty Tabika Kemas were selected via stratified sampling and the teacher selected met the required criteria in this study. The teaching styles studied are expert teaching styles, formal authority, personal model and delegate teaching style. The instrument used in this research is a modified Teaching Styles Inventory questionnaire from Grasha (1996). A total of 50 Kemas teachers were 
involved as a sample of the study. All data obtained were analyzed using Statistical Packages for Social Science (SPSS) Version 22.0. The results of this study were teachers' teaching style (min 3.5), formal authority (min 3.37), interpersonal model (min 3.5), facilitator (min 3.88) and delegate teaching style (min 4.06). The findings show that most teacher use delegate teaching style ( mean 4.06) while the lest teaching style is the facilitator teaching style (mean 3.38). In summary, teachers in Tabika Kemas use delegate teaching styles, as their educational background is not formal in early childhood education.

Keywords: teaching, teaching style, teaching style Grasha,

\section{PENGENALAN}

Malaysia kini sedang memasuki fasa 15 tahun yang kedua ke arah mencapai Wawasan 2020 (Hasrat menjadi sebuah negara maju mengikut acuan sendiri). Selaras dengan itu, salah satu agenda penting kerajaan adalah untuk membangunkan satu sistem pendidikan bertaraf dunia. Oleh itu Kementerian Pelajaran mempunyai tanggungjawab yang amat besar dalam membangunkan modal insan yang bersifat menyeluruh, progresif, bermoral dan beretika tinggi selain daripada melahirkan modal insan berpengetahuan dan berkemahiran.

Pendidikan prasekolah merupakan asas dalam memberi pengetahuan dan kemahiran awal kepada kanak-kanak berumur lima hingga enam tahun. Pada peringkat umur ini kanak-kanak mudah untuk menyerap pengetahuan dan kemahiran yang diberikan oleh guru semasa proses pengajaran dan pembelajaran. Pengetahuan dan kemahiran awal yang diberikan mestilah berdasarkan perkembangan yang bersesuaian dengan peringkat umur kanak-kanak supaya ia mudah diterima dan menjadikan pembelajaran lebih bermakna dan berkesan. Dalam menjayakan visi ini, tenaga kerja yang berpengetahuan, kompeten dan berdisiplin serta mempunyai daya kreativiti yang tinggi merupakan ramuan penting yang tidak dapat dielakkan. Disamping itu juga aspek produktiviti yang tinggi melalui penggunaan kepelbagaian kemahiran, inovasi, kreativiti dan peningkatan kecekapan bagi melahirkan bakat atau modal insan terbaik menjadi agenda yang diutamakan ke arah merealisasikan Wawasan 2020. MEB yang dilancarkan oleh Dato' Seri Najib Tun Razak dan Visi 2057 yang telah dicetuskan oleh Tun Abdullah Ahmad Badawi sememangnya mempunyai nada yang serupa, iaitu menjurus kepada melahir dan membina modal insan berkualiti tinggi demi menjayakan Wawasan 2020. Menurut Grasha (1994), seorang guru mungkin menggunakan lebih daripada satu gaya pengajaran dan digabungkan dalam empat kategori. Empat kategori yang telah dikenal pasti oleh Grasha yang terdiri daripada: Kategori 1: iaitu gaya pengajaran pakar dan gaya pengajaran autoriti formal. Kategori 2: iaitu gaya model peribadi dan gaya pakar serta gaya 
autoriti formal. 3: iaitu gaya fasilitator dan gaya model peribadi serta gaya pakar. Kategori 4: iaitu gaya delegator dan gaya fasilitator serta gaya pakar.

\section{Pernyataan Masalah}

Masalah utama yang disebut dalam Pelan Pembangunan Pendidikan Malaysia 2013-2025 (KPM, 2013) ialah mengenai kemerosotan pencapaian pelajar-pelajar Malaysia dalam PISA dan TIMSS 2009, khususnya dalam mata pelajaran Sains dan Matematik. Salah satu faktor yang menyebabkan merosotnya kedudukan Malaysia dalam pentaksiran pendidikan antarabangsa ini ialah kerana pelajar Malaysia sudah terbiasa belajar secara menghafal fakta-fakta rote learning tanpa pemahaman mendalam tentang konsep-konsep yang dipelajari, dan kurangnya penekanan diberikan kepada pembinaan kemahiran berfikir peringkat tinggi dan kemahiran penyelesaian masalah (KPM, 2013).

Dari segi kandungan pembelajaran, didapati sukatan pelajaran Sains dan Matematik yang disediakan di semua peringkat pengajian sangat kurang menekankan aplikasi dalam kehidupan sebenar. Pelajar merasa pembelajaran mereka kurang bermakna, tidak mencabar dan tidak relevan dengan kehidupan seharian (Aminah Ayob, 2012; Norazilawati Abdullah, Nik Azmah Nik Yusuff, \& Rosnidar Mansor, 2012).

Kualiti pengajaran dan pembelajaran dalam pendidikan prasekolah dinilai dari hasil kemenjadian kanak-kanak prasekolah melalui pendekatan yang digunakan oleh guru-guru prasekolah. Kemenjadian kanak-kanak bukan sahaja dilihat daripada aspek pencapaian akademik tetapi pengetahuan dan kemahiran yang diperoleh oleh mereka semasa di prasekolah dapat diaplikasikan apabila memasuki sekolah rendah dan juga dalam kehidupan seharian mereka. Dalam Kurikulum Standard Prasekolah Kebangsaan (2010) penekanan diberi terhadap penggunaan pendekatan yang menyokong pembangunan komuniti murid prasekolah yang kreatif dan berfikiran terbuka melalui aktiviti-aktiviti yang memberi peluang kepada mereka untuk melibatkan diri dalam proses membuat keputusan dan bertanggungjawab terhadap pembelajaran sendiri. Beberapa pendekatan yang bersesuaian dengan tahap perkembangan kanak-kanak telah dicadangkan dalam Kurikulum Standard Prasekolah Kebangsaan, termasuklah pendekatan projek.

Walaupun banyak penyelidikan mengenai kesan pelaksanaan pendekatan projek di negara-negara barat tetapi amat kurang penyelidikan yang dibuat dan diterbitkan di Malaysia terutamanya penyelidikan di peringkat prasekolah. Contoh kajian yang telah dibuat mengenai pendekatan projek di prasekolah ialah kajian oleh Saemah Rahman, Ruhizan Yasin dan Siti 
Fatimah (2010), Noor Miza Abdul Rahman, Anna Christina Abdullah dan Aznan Che Ahmad (2012), dan Sharifah Nor Puteh dan Romarzila Omar (2013).

Menurut Kamarul, Noratikah \& Mohd Faeez (2012), menjadi seorang guru yang berkesan dalam pengajaran dan pembelajaran bukanlah suatu perkara yang mudah. Semuanya adalah bergantung kepada gaya pengajaran guru itu sendiri. Pengalaman mempengaruhi gaya pengajaran dan pembelajaran guru selain daripada penerapan ilmu pengetahuan yang dimiliki. Adapun ciri guru yang berkesan itu bergantung kepada gaya pengajaran dan pembelajaran yang diamalkan melalui pengalaman dan pengetahuan yang dimiliki. Maka kekerapan dalam menerapkan gaya pengajaran banyak mempengaruhi keberkesanan pengajaran dan pembelajaran seseorang guru.

Oleh itu pengkaji berminat untuk menjalankan kajian ini dengan tujuan memberi pendedahan kepada guru-guru prasekolah. Kesan pendekatan ini untuk meningkatkan perkembangan akhlak kanak-kanak prasekolah di Malaysia.

\section{Objektif Kajian}

Objektif kajian ini adalah :

1. Mengenalpasti gaya pengajaran guru-guru dalam pendidikan awal kanak-kanak di Tabika Kemas negeri Kelantan

2. Mengenalpasti gaya pengajaran yang dominan dalam pendidikan awal kanak-kanak di Tabika Kemas negeri Kelantan

\section{Persoalan Kajian}

Persoalan kajian ini adalah :

1. Apakah gaya pengajaran guru-guru dalam pendidikan awal kanak-kanak di Tabika Kemas negeri Kelantan?

2. Apakah gaya pengajaran yang dominan dalam pendidikan awal kanak-kanak negeri Kelantan?

\section{Metodologi Kajian}

Kajian yang dijalankan adalah berbentuk deskriptif. Kajian ini dijalankan secara kuantitatif melibatkan 50 orang guru Tabika Kemas di Kelantan. Instrumen yang digunakan dalam kajian ini ialah soal selidik yang telah diubah suai daripada Grasha (1996) iaitu Inventori Gaya Mengajar Guru Teaching Styles Inventory. Data telah dianalisis menggunakan kaedah 
statistik deskriptif iaitu min, frekuensi dan peratus. Guru yang terlibat dalam kajian ini adalah terdiri daripada beberapa daerah di negeri Kelantan iaitu daerah Kota Bahru, Ketereh, Pengkalan Chepa, Kubang Kerian, Pasir Mas dan Tumpat.

\section{Kajian Lepas}

Menurut kajian yang dijalankan oleh Robin, F (2011) ke atas 20 orang guru, didapati bahawa faktor yang membawa kepada peningkatan kognitif kanak-kanak adalah gaya kepimpinan guru dalam pengajaran adalah amat penting. Menurut Azilah (2010), mendapati bahawa gaya pengajaran secara peribadi menunjukkan min tertinggi dalam kajiannya, ini kerana matematik memerlukan perhatian individu dan latihan yang kerap membantu meningkatkan pencapaian akademik seseorang. Gaya pengajaran dalam kelas memainkan peranan yang penting dalam membantu meningkatkan pencapaian akademik seseorang pelajar.

Courtney Beers (2016), tujuan kajiannya adalah untuk mengetahui amalan pedagogi yang sesuai untuk kanak-kanak. Hasil kajiannya mendapati pengalaman dan persediaan guru adalah penting untuk meningkatkan mutu pembelajaran anak-anak. Gaya pengajaran guru perlu diutamakan untuk menghasilkan pembelajaran yang berkualiti. Cindi H., F (2012) menyatakan bahawa falsafah pendidikan dan gaya pengajaran memberikan kesan ke atas pembelajaran kanak-kanak di tadika. Gaya pengajaran merupakan bahagian penting sebagai pendidik. Ia memerlukan proses penerokaan, refleksi dan aplikasi yang berterusan yang menuntut mengetahui sendiri nilai dan kepercayaan. Sepanjang proses penerokaan dan refleksi pelajar dapat meneroka dan pengamalan sendiri apabila guru sebagai fasilitator dalam proses pengajaran dan pembelajaran.

Wastin, Ellie and Han, H. Sophia (2017) kajian tindakan yang dijalankan oleh guru prasekolah dalam kelas Tadika. Terdapat dua matlamat untuk penyelidikan tindakan ini: (a) untuk mempertingkatkan soal siasat pengawasan guru dan strategi pengurusan kelas, dan (b) untuk meningkatkan penyelidikan sains dan pengetahuan anak-anak. Hasil kajian mendapati bahawa strategi, pembelajaran berpusatkan pelajar dan pengurusan kelas memainkan peranan penting di sesebuah tadika. Gaya pengajaran guru sebagai fasilitator membantu pengajaran dan pembelajaran meningkatkan lagi pengetahuan kanak-kanak.

Kajian yang dijalankan oleh Siti Maria dan Zamri (2016), ke atas pencapaian murid dalam bahasa arab yang mengalami penurunan. Hasil kajian yang dijalankan adalah penerapan gaya pengajaran Grasha dikatakan mempengaruhi peningkatan pencapaian murid. Hasil analisis kajian ini mendapati guru KAFA Integrasi mengamalkan gaya pengajaran pakar Grasha. 
Implikasi analisis kajian menunjukkan bahawa guru perlu memantapkan dan menguasai gaya pengajaran Grasha yang lain agar dapat meningkatkan pencapaian dan dapat menarik minat murid untuk mempelajari bahasa Arab. Kajian ini melibatkan 60 buah sekolah KAFA Integrasi dengan bilangan responden seramai 260 orang yang terdiri daripada sekolah bandar dan luar bandar.

Kajian Roslind (2003), tentang "Hubungan gaya pengajaran dengan sikap murid terhadap bahasa Melayu". Hasil kajian mendapati bahawa guru begitu cenderung mengamalkan gaya pengajaran model personal, gaya fasilitator dan gaya autoriti formal, tetapi kurang menggunakan gaya delegator dan gaya pakar. Manakala kajian Vicky (2005), "Hubungan antara gaya pengajaran guru dengan pencapaian pelajar dalam mata pelajaran Matematik Tambahan", mendapati guru telah mengaplikasikan kelima-lima gaya dalam pengajaran namun gaya yang sering diamalkan adalah gaya model personal, gaya pakar dan gaya autoriti formal. Ini menunjukkan gaya pengajaran yang paling dominan dalam kajian ini adalah gaya model personal. Begitu juga kajian yang dijalankan oleh Abd. Aziz (2010) ke atas 189 orang pelajar tingkatan enam atas di tujuh buah sekolah di daerah Johor Bahru mendapati gaya pengajaran yang sangat digemari adalah gaya pengajaran model personal, diikuti dengan gaya pengajaran fasilitator dan gaya pengajaran pakar. Manakala gaya pengajaran yang kurang diminati adalah gaya pengajaran delegator dan gaya pengajaran autoriti formal.

\section{Analisis Data}

Data dianalisis berdasarkan persoalan kajian.

Persoalan kajian pertama:

1. Apakah gaya pengajaran guru-guru dalam pendidikan awal kanak-kanak di Tabika Kemas negeri Kelantan?

\section{Analisis Deskriptif Gaya Pengajaran Pakar}

Jadual 1: Taburan Maklum Balas Terhadap Setiap Item Gaya Pengajaran Pakar

\begin{tabular}{|c|c|c|c|c|c|c|}
\hline Item & 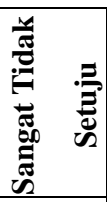 & 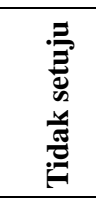 & 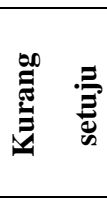 & 苐 & 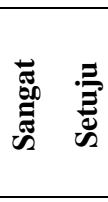 & $\stackrel{\Xi}{\Sigma}$ \\
\hline $\begin{array}{l}\text { Fakta, konsep, dan prinsip adalah perkara } \\
\text { yang paling Penting yang pelajar harus } \\
\text { perolehi. }\end{array}$ & $\begin{array}{c}1 \\
(2.0)\end{array}$ & $\begin{array}{c}27 \\
(54.0)\end{array}$ & $\begin{array}{c}21 \\
(42)\end{array}$ & $\begin{array}{c}1 \\
(2.0)\end{array}$ & $\begin{array}{c}0 \\
(0)\end{array}$ & 5.0 \\
\hline
\end{tabular}




\begin{tabular}{|c|c|c|c|c|c|c|}
\hline $\begin{array}{l}\text { Saya menetapkan standard yang tinggi bagi } \\
\text { pencapaian pelajar saya }\end{array}$ & $\begin{array}{c}3 \\
(6.0)\end{array}$ & $\begin{array}{c}25 \\
(50.0)\end{array}$ & $\begin{array}{c}19 \\
(38.0)\end{array}$ & $\begin{array}{c}3 \\
(6.0)\end{array}$ & $\begin{array}{c}0 \\
(0)\end{array}$ & 3.0 \\
\hline $\begin{array}{l}\text { Apa yang saya kata dan lakukan merupakan } \\
\text { model yang boleh diikuti oleh pelajar untuk } \\
\text { mempelajari sesuatu. }\end{array}$ & $\begin{array}{c}2 \\
(4.0)\end{array}$ & $\begin{array}{c}26 \\
(52.0)\end{array}$ & $\begin{array}{c}20 \\
(40.0)\end{array}$ & $\begin{array}{c}2 \\
(4.0)\end{array}$ & $\begin{array}{l}0 \\
(0)\end{array}$ & 4.0 \\
\hline $\begin{array}{l}\text { Matlamat dan kaedah pengajaran saya } \\
\text { mengambil kira } \\
\text { kepelbagaian gaya belajar pelajar. }\end{array}$ & $\begin{array}{c}3 \\
(6.0)\end{array}$ & $\begin{array}{c}24 \\
(48.0)\end{array}$ & $\begin{array}{c}18 \\
(36.0)\end{array}$ & $\begin{array}{c}5 \\
(10)\end{array}$ & $\begin{array}{l}0 \\
(0)\end{array}$ & 4.0 \\
\hline $\begin{array}{l}\text { Pelajar biasanya menyiapkan kerja kursus } \\
\text { secara sendirian dengan sedikit bimbingan } \\
\text { daripada saya. }\end{array}$ & $\begin{array}{c}3 \\
(6.0)\end{array}$ & $\begin{array}{c}24 \\
(48.0)\end{array}$ & $\begin{array}{c}18 \\
(36.0)\end{array}$ & $\begin{array}{c}5 \\
(10.0 \\
)\end{array}$ & $\begin{array}{l}0 \\
(0)\end{array}$ & 4.0 \\
\hline $\begin{array}{l}\text { Berkongsi pengetahuan dan kemahiran } \\
\text { dengan pelajar sangat penting bagi saya. }\end{array}$ & $\begin{array}{c}1 \\
(2.0)\end{array}$ & $\begin{array}{c}35 \\
(70.0)\end{array}$ & $\begin{array}{c}13 \\
(26.0)\end{array}$ & $\begin{array}{c}1 \\
(2.0)\end{array}$ & $\begin{array}{l}0 \\
(0)\end{array}$ & 3.0 \\
\hline $\begin{array}{l}\text { Saya berikan pelajar maklum balas negatif } \\
\text { jika prestasinya tidak memuaskan. }\end{array}$ & $\begin{array}{c}7 \\
(2.0)\end{array}$ & $\begin{array}{c}28 \\
(56.0)\end{array}$ & $\begin{array}{c}20 \\
(40.0)\end{array}$ & $\begin{array}{c}1 \\
(2.0)\end{array}$ & $\begin{array}{l}0 \\
(0)\end{array}$ & 1.0 \\
\hline $\begin{array}{l}\text { Kegiatan di kelas dapat mendorong pelajar } \\
\text { untuk mengembangkan idea mereka sendiri } \\
\text { tentang sesuatu kandungan pengetahuan. }\end{array}$ & $\begin{array}{c}1 \\
(2.0)\end{array}$ & $\begin{array}{c}26 \\
(52.0)\end{array}$ & $\begin{array}{c}20 \\
(40.0)\end{array}$ & $\begin{array}{c}2 \\
(4.0)\end{array}$ & $\begin{array}{l}0 \\
(0)\end{array}$ & 4.0 \\
\hline \multicolumn{6}{|c|}{ Purata Min } & 3.50 \\
\hline
\end{tabular}

Jadual 1 di atas menunjukkan maklum balas responden terhadap setiap item gaya pengajaran pakar. Item 1 menunjukkan nilai min yang tinggi. Didapati seramai 27 orang dengan $(54.0 \%)$ tidak setuju dan 21 orang (42.0\%) lagi kurang setuju terhadap item 'Fakta, konsep, dan prinsip adalah perkara yang paling penting yang pelajar harus perolehi. '. Manakala 1 orang $(2.0 \%)$ sahaja menyatakan setuju, dan selebihnya 1 orang $(2.0 \%)$ sangat tidak setuju.

Manakala item 3, 4, 5 dan 8 juga berada pada min tertinggi. Bagi item 3 "Apa yang saya kata dan lakukan merupakan model yang boleh diikuti oleh pelajar untuk mempelajari sesuatu" menunjukkan hanya 26 orang $(52.0 \%)$ memilih skor tidak setuju, 20 orang (40.0 \%) memilih kurang setuju. 2 orang $(4.0 \%)$ memilih sangat tidak setuju dan 2 orang (4.0\%) dan 5 orang (4.4\%) memilih setuju.

Keseluruhannya, gaya pengajaran pakar menunjukkan nilai min purata sebanyak 3.50. 


\section{Analisis Deskriptif Gaya Pengajaran Autoriti Formal}

Jadual 2: Taburan Maklum Balas Terhadap Setiap Item Gaya Pengajaran Autoriti Formal.

\begin{tabular}{|c|c|c|c|c|c|c|}
\hline Item & 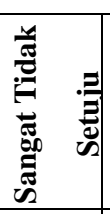 & 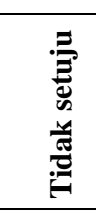 & 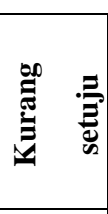 & 言 & 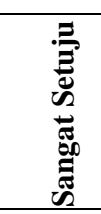 & $\stackrel{\Xi}{\Sigma}$ \\
\hline $\begin{array}{l}\text { Saya menghabiskan masa untuk berunding dengan } \\
\text { pelajar tentang cara meningkatkan prestasi mereka } \\
\text { secara individu dan / atau kelompok. }\end{array}$ & $\begin{array}{c}2 \\
(4.0)\end{array}$ & $\begin{array}{c}26 \\
(52.0)\end{array}$ & $\begin{array}{c}20 \\
(40.0)\end{array}$ & $\begin{array}{c}2 \\
(4.0)\end{array}$ & - & 4.0 \\
\hline $\begin{array}{l}\text { Kegiatan di kelas dapat mendorong pelajar untuk } \\
\text { mengembangkan idea mereka sendiri tentang } \\
\text { sesuatu kandungan pengetahuan. }\end{array}$ & $\begin{array}{c}1 \\
(2.0)\end{array}$ & $\begin{array}{c}11 \\
(22.0)\end{array}$ & $\begin{array}{c}19 \\
(38.0)\end{array}$ & $\begin{array}{c}17 \\
(34.0)\end{array}$ & - & 3.0 \\
\hline $\begin{array}{l}\text { Apa yang harus saya katakan tentang topik } \\
\text { pengajaran saya adalah penting bagi pelajar untuk } \\
\text { mendapatkan perspektif yang lebih luas terhadap } \\
\text { sesuatu perkara. }\end{array}$ & - & $\begin{array}{c}7 \\
(14.0)\end{array}$ & $\begin{array}{c}21 \\
(42.0)\end{array}$ & $\begin{array}{c}19 \\
(38.0)\end{array}$ & $\begin{array}{c}2 \\
(4.0)\end{array}$ & 4.0 \\
\hline $\begin{array}{l}\text { Pelajar akan mendapati akan piawai dan harapan } \\
\text { saya } \\
\text { adalah sesuatu yang tegas dan rigid. }\end{array}$ & - & $\begin{array}{c}10 \\
(20.0)\end{array}$ & $\begin{array}{c}22 \\
(44.0)\end{array}$ & $\begin{array}{c}16 \\
(32.0)\end{array}$ & $\begin{array}{c}2 \\
(4.0)\end{array}$ & 2.0 \\
\hline $\begin{array}{l}\text { Saya biasanya menunjukkan pelajar bagaimana } \\
\text { dan apa yang harus dilakukan dalam rangka untuk } \\
\text { menguasai isi kandungan pelajaran. }\end{array}$ & - & $\begin{array}{c}2 \\
(4.0)\end{array}$ & $\begin{array}{c}2 \\
(4.0)\end{array}$ & $\begin{array}{c}31 \\
(62.0)\end{array}$ & $\begin{array}{c}15 \\
(30.0)\end{array}$ & 3.0 \\
\hline $\begin{array}{l}\text { Perbincangan kumpulan kecil digunakan untuk } \\
\text { membantu pelajar mengembangkan kemampuan } \\
\text { mereka untuk berfikir secara kritis. }\end{array}$ & - & - & $\begin{array}{c}3 \\
(6.0)\end{array}$ & $\begin{array}{c}35 \\
(70.0)\end{array}$ & $\begin{array}{c}12 \\
(24.0)\end{array}$ & 4.0 \\
\hline $\begin{array}{l}\text { Pelajar boleh belajar sendiri dengan pelbagai } \\
\text { kaedah } \\
\text { pembelajaran kendiri. }\end{array}$ & - & - & $\begin{array}{c}1 \\
(2.0)\end{array}$ & $\begin{array}{c}31 \\
(62.0)\end{array}$ & $\begin{array}{c}18 \\
(36.0)\end{array}$ & 4.0 \\
\hline $\begin{array}{l}\text { Saya mahu pelajar tinggalkan kursus ini dalam } \\
\text { keadaan mereka lebih bersedia belajar lebih lanjut } \\
\text { dalam perkara ini. }\end{array}$ & - & - & $\begin{array}{c}2 \\
(4.0)\end{array}$ & $\begin{array}{c}29 \\
(58.0)\end{array}$ & $\begin{array}{c}19 \\
(38.0)\end{array}$ & 3.0 \\
\hline Purata Min & 3.37 & & & & & \\
\hline
\end{tabular}


Jadual 2 menunjukkan maklum balas responden terhadap setiap item gaya pengajaran autoriti formal. Item 9, 14 dan 15 menunjukkan min tinggi. Bagi Item 9 iaitu ' Saya menghabiskan masa untuk berunding dengan pelajar tentang cara meningkatkan prestasi mereka secara individu dan / atau kelompok ' didapati 26 orang (52.0\%) tidak setuju dan 20 orang (40.0\%) lagi kurang setuju dengan item tersebut. Manakala 2 orang (4.0\%) sahaja menyatakan sangat tidak setuju, dan selebihnya 2 orang $(4.0 \%)$ dengan setuju.

Keseluruhannya, gaya pengajaran autoriti formal menunjukkan nilai min purata sebanyak 3.37 .

\section{Analisis Deskriptif Gaya Pengajaran Model Personal}

Jadual 3: Taburan Maklum balas Terhadap Setiap Item Model Interpersonal.

\begin{tabular}{|c|c|c|c|c|c|c|}
\hline Item & 荡 & 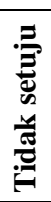 & 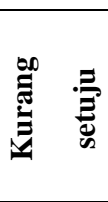 & 韵 & 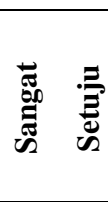 & 涪 \\
\hline $\begin{array}{l}\text { Untuk menentukan apa yang pelajar harus belajar } \\
\text { dan } \\
\text { bagaimana mereka harus mempelajarinya. }\end{array}$ & - & - & - & $\begin{array}{c}36 \\
(72.0)\end{array}$ & $\begin{array}{c}14 \\
(28.0)\end{array}$ & 3.0 \\
\hline $\begin{array}{l}\text { Contoh dari pengalaman saya sering digunakan } \\
\text { sebagai sumber bahan rujukan. }\end{array}$ & - & - & $\begin{array}{c}1 \\
(2.0)\end{array}$ & $\begin{array}{c}31 \\
(62.0)\end{array}$ & $\begin{array}{c}18 \\
(36.0)\end{array}$ & 4.0 \\
\hline $\begin{array}{l}\text { Saya membimbing kerja-kerja pelajar dengan } \\
\text { mengajukan soalan, menerokai pilihan, dan } \\
\text { menyarankan cara-cara alternatif untuk } \\
\text { menyelesaikan sesuatu tugasan. }\end{array}$ & - & - & $\begin{array}{c}1 \\
(2.0)\end{array}$ & $\begin{array}{c}32 \\
(66.0)\end{array}$ & $\begin{array}{c}16 \\
(32.0)\end{array}$ & 4.0 \\
\hline $\begin{array}{l}\text { Mengembangkan kemampuan pelajar untuk } \\
\text { berfikir dan bekerja secara berdikari merupakan } \\
\text { tujuan penting. }\end{array}$ & - & - & $\begin{array}{c}1 \\
(2.0)\end{array}$ & $\begin{array}{c}32 \\
(64.0)\end{array}$ & $\begin{array}{c}17 \\
(34.0)\end{array}$ & 3.0 \\
\hline $\begin{array}{l}\text { Bersyarah merupakan bahagian penting daripada } \\
\text { cara } \\
\text { saya mengajar pada setiap sesi kelas. }\end{array}$ & - & - & - & $\begin{array}{c}29 \\
(58.0)\end{array}$ & $\begin{array}{c}21 \\
(42.0)\end{array}$ & 4.0 \\
\hline $\begin{array}{l}\text { Saya berikan panduan yang sangat jelas tentang } \\
\text { bagaimana saya ingin sesuatu tugasan disiapkan. }\end{array}$ & - & - & $\begin{array}{c}2 \\
(4.0)\end{array}$ & $\begin{array}{c}27 \\
(54.0)\end{array}$ & $\begin{array}{c}21 \\
(42.0)\end{array}$ & 4.0 \\
\hline $\begin{array}{l}\text { Saya sering menunjukkan pelajar bagaimana } \\
\text { mereka } \\
\text { boleh menggunakan pelbagai prinsip dan konsep } \\
\text { dalam pembelajaran mereka. }\end{array}$ & - & - & - & $\begin{array}{c}24 \\
(48.0)\end{array}$ & $\begin{array}{c}26 \\
(52.0)\end{array}$ & 2.0 \\
\hline
\end{tabular}




\begin{tabular}{|l|c|c|c|c|c|c|}
\hline $\begin{array}{l}\text { Aktiviti pembelajaran dapat mendorong pelajar } \\
\text { untuk }\end{array}$ & & & & & & \\
mengambil inisiatif dan tanggung jawab dalam \\
pembelajaran mereka.
\end{tabular}

Jadual 3 menunjukkan maklum balas responden terhadap setiap item gaya pengajaran model interpersonal. Item 18, 19, 21, 22 dan 24 menunjukkan min tertinggi. Bagi Item 18 iaitu ' Contoh dari pengalaman saya sering digunakan sebagai sumber bahan rujukan' mempunyai 31 orang $(62.0 \%)$ setuju dengan kenyataan ini dan 18 orang $(36.0 \%)$ lagi sangat setuju. Manakala hanya 1 orang (2.0\%) sahaja menyatakan kurang setuju.

Bagi item 19, iaitu 'Saya membimbing kerja-kerja pelajar dengan mengajukan soalan,menerokai pilihan, dan menyarankan cara-cara alternatif untuk menyelesaikan sesuatu tugasan'. Hasil kajian menunjukkan mempunyai 33 orang (66.0\%) setuju dengan kenyataan ini dan 16 orang $(32.0 \%)$ lagi sangat setuju. Manakala hanya 1 orang $(2.0 \%)$ sahaja menyatakan kurang setuju.

Keseluruhannya, faktor hubungan interpersonal menunjukkan nilai min purata sebanyak 3.50. 


\section{Analisis Deskriptif Gaya Pengajaran Responden}

Jadual 4: Taburan Maklum Balas Terhadap Setiap Item Fasilitator.

\begin{tabular}{|c|c|c|c|c|c|c|}
\hline Item & 莺 & 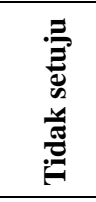 & 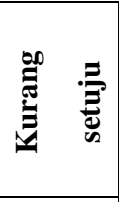 & 葛 & 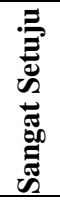 & $\equiv$ \\
\hline $\begin{array}{l}\text { Pelajar mengambil tanggungjawab untuk } \\
\text { mengajar rakan sebahagian dari sesi kelas. }\end{array}$ & - & - & $\begin{array}{c}8 \\
(16.0)\end{array}$ & $\begin{array}{c}42 \\
(84.0)\end{array}$ & - & 3.84 \\
\hline $\begin{array}{l}\text { Kepakaran saya biasanya digunakan untuk } \\
\text { menyelesaikan perbezaan pendapat tentang } \\
\text { sesuatu isu. }\end{array}$ & - & $\begin{array}{c}8 \\
(16.0)\end{array}$ & - & $\begin{array}{c}42 \\
(84.0)\end{array}$ & - & 3.68 \\
\hline $\begin{array}{l}\text { Kursus ini memiliki tujuan dan objektif } \\
\text { yang khusus } \\
\text { yang ingin saya capai. }\end{array}$ & - & - & $\begin{array}{c}12 \\
(24.0)\end{array}$ & $\begin{array}{c}38 \\
(76.0)\end{array}$ & - & 3.76 \\
\hline $\begin{array}{l}\text { Pelajar sering menerima komen secara lisan } \\
\text { atau bertulis mengenai prestasi mereka. }\end{array}$ & - & - & $\begin{array}{c}12 \\
(24.0)\end{array}$ & $\begin{array}{c}38 \\
(76.0)\end{array}$ & - & 3.76 \\
\hline $\begin{array}{l}\text { Saya meminta pandangan pelajar tentang } \\
\text { bagaimana dan apa yang akan diajarkan } \\
\text { dalam sesuatu kursus. }\end{array}$ & - & - & - & $\begin{array}{c}50 \\
(100)\end{array}$ & - & 4.0 \\
\hline $\begin{array}{l}\text { Pelajar menetapkan sendiri kadar/tempoh } \\
\text { untuk menyelesaikan projek kumpulan. }\end{array}$ & - & - & - & $\begin{array}{c}50 \\
(100)\end{array}$ & - & 4.0 \\
\hline $\begin{array}{l}\text { Pelajar boleh menggambarkan saya sebagai } \\
\text { "gudang pengetahuan" yang mengeluarkan } \\
\text { suatu fakta, prinsip, dan konsep yang } \\
\text { mereka perlukan. }\end{array}$ & - & - & - & $\begin{array}{c}50 \\
(100)\end{array}$ & - & 4.0 \\
\hline $\begin{array}{l}\text { Harapan saya untuk apa yang ingin pelajar } \\
\text { saya lakukan dalam kelas ini secara jelas } \\
\text { ditakrifkan dalam sukatan. }\end{array}$ & - & - & - & $\begin{array}{c}50 \\
(100)\end{array}$ & - & 4.0 \\
\hline \multicolumn{6}{|c|}{ Jumlah Purata } & 3.88 \\
\hline
\end{tabular}

Jadual 4 menunjukkan maklum balas responden terhadap setiap item gaya pengajaran fasilitator. Item 29, 30, 31 dan 32 menunjukkan nilai min tertinggi iaitu 4. Di dapati 50 orang dengan $(100.0 \%)$ setuju dengan item tersebut. 
Item 26 mencatatkan nilai min yang rendah iaitu 3.68. Kenyataan 'Kepakaran saya biasanya digunakan untuk menyelesaikan perbezaan pendapat tentang sesuatu isu. Di mana majoriti responden memilih skor setuju iaitu 42 orang dengan $(84.0 \%)$ dan hanya 8 orang dengan (16.0\%) tidak setuju. Keseluruhannya, bagi gaya pengajaran fasilitator pula menunjukkan nilai min purata sebanyak 3.88 .

\section{Analisis Deskriptif Gaya Pengajaran Responden}

Jadual 5: Taburan Maklum Balas Terhadap Setiap Item Delegator.

\begin{tabular}{|c|c|c|c|c|c|c|}
\hline Item & 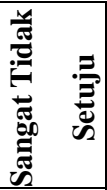 & 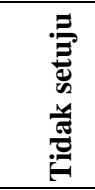 & 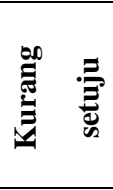 & 营 & 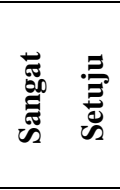 & $\equiv$ \\
\hline $\begin{array}{l}\text { Akhirnya, banyak pelajar mula } \\
\text { berfikir seperti saya tentang isi } \\
\text { pelajaran yang diajar. }\end{array}$ & - & - & $\begin{array}{c}20 \\
(40.0)\end{array}$ & $\begin{array}{c}23 \\
(46.0)\end{array}$ & $\begin{array}{c}7 \\
(14)\end{array}$ & 3.74 \\
\hline $\begin{array}{l}\text { Pelajar boleh membuat pilihan } \\
\text { antara aktiviti dalam memenuhi } \\
\text { keperluan kursus mereka. }\end{array}$ & - & - & $\begin{array}{c}34 \\
(68.0)\end{array}$ & $\begin{array}{c}14 \\
(28.0)\end{array}$ & $\begin{array}{c}2 \\
(4.0)\end{array}$ & 3.66 \\
\hline $\begin{array}{l}\text { Pendekatan saya untuk mengajar } \\
\text { adalah sama dengan seorang } \\
\text { pengurus dari sebuah kumpulan } \\
\text { kerja yang membahagikan tugas dan } \\
\text { tanggungjawabnya kepada bawahan. }\end{array}$ & - & $\begin{array}{c}13 \\
(26.0)\end{array}$ & $\begin{array}{c}6 \\
(12.0)\end{array}$ & $\begin{array}{c}16 \\
(32.0)\end{array}$ & $\begin{array}{c}15 \\
(30.0)\end{array}$ & 4.0 \\
\hline $\begin{array}{l}\text { Terdapat banyak bahan dalam kursus } \\
\text { ini berbanding tempoh masa yang } \\
\text { diperuntukkan. }\end{array}$ & - & - & - & $\begin{array}{c}50 \\
(100)\end{array}$ & - & 4.28 \\
\hline $\begin{array}{l}\text { Piawaian dan harapan saya dapat } \\
\text { membantu pelajar membina disiplin } \\
\text { yang diperlukan untuk belajar. }\end{array}$ & - & - & - & $\begin{array}{c}36 \\
(72.0)\end{array}$ & $\begin{array}{c}14 \\
(28.0)\end{array}$ & 4.28 \\
\hline $\begin{array}{l}\text { Pelajar boleh menggambarkan saya } \\
\text { sebagai seorang "pelatih" yang } \\
\text { bekerja sama dengan seseorang } \\
\text { untuk memperbaiki masalah dalam } \\
\text { cara mereka berfikir dan bertindak. }\end{array}$ & - & - & - & $\begin{array}{c}31 \\
(62.0)\end{array}$ & $\begin{array}{c}19 \\
(38.0)\end{array}$ & 4.38 \\
\hline
\end{tabular}




\begin{tabular}{|c|c|c|c|c|c|c|}
\hline $\begin{array}{l}\text { Saya memberikan pelajar banyak } \\
\text { sokongan peribadi dan dorongan } \\
\text { untuk meningkatkan pencapaian } \\
\text { dalam kursus ini. }\end{array}$ & - & - & - & $\begin{array}{c}31 \\
(62.0)\end{array}$ & $\begin{array}{c}19 \\
(38.0)\end{array}$ & 4.38 \\
\hline $\begin{array}{l}\text { Saya berperanan sebagai sumber } \\
\text { rujukan yang tersedia untuk pelajar } \\
\text { bila-bila masa mereka memerlukan } \\
\text { bantuan. }\end{array}$ & - & - & - & $\begin{array}{c}10 \\
(20.0)\end{array}$ & $\begin{array}{c}40 \\
(80.0)\end{array}$ & 4.80 \\
\hline \multicolumn{6}{|c|}{ Jumlah Purata } & 4.06 \\
\hline
\end{tabular}

Jadual 5 menunjukkan maklum balas responden terhadap setiap item gaya pengajaran delegator. Item 40 menunjukkan nilai min tertinggi iaitu 4.80. Saya berperanan sebagai sumber rujukan yang tersedia untuk pelajar bila-bila masa mereka memerlukan bantuan. Di dapati 40 orang dengan (100.0\%) sangat setuju dan 10 orang dengan (20.0\%) setuju dengan item tersebut.

Keseluruhannya, bagi gaya pengajaran delegator ini pula menunjukkan nilai min purata sebanyak 4.06.

\section{Persoalan Kajian kedua}

2. Apakah gaya pengajaran yang dominan dalam pendidikan awal kanak-kanak negeri Kelantan ?

Jadual 6: Ringkasan Purata Min Bagi Gaya Pengajaran Guru-guru Kemas di Negeri Kelantan

\begin{tabular}{l|c}
\hline Gaya Pengajaran & Min Purata \\
\hline Fasilitator & 3.88 \\
\hline Delegator & \\
\hline
\end{tabular}




\begin{tabular}{l|c}
\hline Model Interpersonal & 3.50 \\
\hline Pakar & 3.50 \\
\hline Formal Autoriti & 3.38 \\
\hline
\end{tabular}

Dari nilai min yang diperolehi menunjukkan kesemua faktor di atas adalah gaya pengajaran guru-guru Kemas di negeri Kelantan. Hasil dapatan kajian menunujukkan sebelum menggunakan pendekatan projek gaya pengajaran utama yang digunakan oleh guru-guru adalah nilai min tertinggi iaitu gaya pengajaran delegator sebagai gaya pengajaran utama, fasilitator sebagai gaya pengajaran kedua, diikuti gaya pengajaran interpersonal dan Pakar diikuti gaya pengajaran akhir adalah formal Autoriti.

\section{Kesimpulan}

Gaya pengajaran dalam pembelajaran amatlah penting. Hasil dapatan kajian mendapati bahawa gaya pengajaran memainkan peranan penting dalam sesi pembelajaran kanak-kanak. Nilai min tertinggi bagi gaya pengajaran guru di Tabika KEMAS sebelum menggunakan gaya pengajaran utama guru adalah delegator.

\section{Rujukan}

Abd. Aziz Abd Samad. (2010). Gaya pengajaran guru dengan sikap pelajar terhadap mata pelajaran Pengajian Perniagaan. Tesis Sarjana. Fakulti Pendidikan, Universiti Kebangsaan Malaysia.

Chua Yan Piaw. (2011). Kaedah dan Statistik Penyelidikan Buku 1 Kaedah Penyelidikan. Ed.2. Kuala Lumpur: Mc Graw Hill Education.

Fries, C. F. (2017). Teaching style preferences and educational philosophy of teacher education faculty at a State University. Oklahoma State University.

Beers, C. (2016). Early childhood preservice teachers' knowledge of children's cognitive development and developmentally appropriate pedagogical practices: Understanding the role of clinical experiences. Florida Atlantic University Boca Raton, Florida: Published.

Mazlini Adnan, Aminah Ayob, Ong Eng Tek, Mohd Nasir Ibrahim, Noriah Ishak \& Jameyah Sheriff. (2016). Memperkasa pembangunan modal insan Malaysia di peringkat kanak-kanak: Kajian kebolehlaksanaan dan kebolehintegrasian pendidikan STEM dalam kurikulum PERMATA Negara. GEOGRAFIA OnlineTM Malaysian Journal of Society and Space 12 issue 1 (29 - 36) 29 (C) 2016, ISSN 2180-2491 
Jurnal Pendidikan Awal Kanak-Kanak Kebangsaan 2017 Special Issue (1-15)

(ISSN 2289-3032 / eISSN 2550-178X)

https://ejournal.upsi.edu.my/journal/JPAK

Fairfield, R. (2011). Early Childhood Educators Teaching and Learning in Professional Learning Communities: A New Approach to Professional Development for. Preschool Teachers in a Southern California School District. College of Education: Walden University.

Roslind Anak Mawing. (2003). Hubungan antara gaya pengajaran guru dengan sikap pelajar terhadap Bahasa Melayu. Kertas Projek Sarjana Pendidikan, Fakulti Pendidikan, Universiti Kebangsaan Malaysia.

Siti Maria Ibrahim \& Zamri Ariffin. e-Jurnal Penyelidikan dan Inovasi Vol. III, No. I (April 2016) 43 -60 e-ISSN 2289-7909

Wastin, Ellie and Han, H. Sophia. (2017). Action research and project approach: Journey of an early childhood pre-service teacher and a teacher educator, Networks: An Online Journal for Teacher Research, 16(2). 